\title{
Non-Tariff Measures in Indian Context and the European Union
}

\author{
Rakhi Singh ${ }^{1}$, Seema Sharma ${ }^{2} \&$ Deepak Tandon ${ }^{3}$ \\ ${ }^{1}$ Research Scholar, Department of Economics, Banasthali University, Jaipur, India \\ ${ }^{2}$ Associate Professor and HOD - Economics, Banasthali University, Jaipur, India \\ ${ }^{3}$ Professor, IMI (International Management Institute) B-10, Qutab Institutional Area New Delhi, India \\ Correspondence: Deepak Tandon, Professor, IMI (International Management Institute) B-10, Qutab Institutional \\ Area New Delhi, India. E-mail: deepaktandon@imi.edu
}

Received: July 7, 2018

doi:10.5539/ijef.v10n9p54
Accepted: August 7, 2018

Online Published: August 15, 2018

URL: https://doi.org/10.5539/ijef.v10n9p54

\begin{abstract}
Indian economy is one of the fastest growing economies in the world today. In line with global trade trends, Indian export sector has been growing and contributing significantly to the economy. Given its exports structure, India is well positioned to benefit from the structural changes in technology and emerging forces of globalization. Indian economy has shown remarkable progress in terms of foreign trade after the introduction of economic reforms in 1991. The European Union (EU) is a very important trading partner of India. The trade volumes between India and EU have shown remarkable improvement in last one and a half decade. After starting out at a relatively low level in the 1990's, the trade volumes, both with respect to Indian exports to the EU as well as with respect to Indian imports from the EU, started to increase most noticeably after the year 2001.Use of non-tariff measures (NTMs) as means of protection has captured a lot of focus after reduction of tariffs in the world trade. India even after being a strategic partner for European Union (EU) has to face lot of NTMs on its exports. Based on studies in the past, link between the incidence of NTMs imposed by the home country and the income level of the foreign country has been established. The interplay of incidence of NTMs and the GDP remains largely unexplored in the context of India-EU trade relationship. This paper tries to fill this gap and show the importance of the study in policy decisions. Authors have used UNCTAD's NTM data and Spearman's correlation coefficient to measure the strength and direction of the relationship between incidence of NTM with per capita GDP of the exporting country (India). The authors have used different permutations of data from the main data set (1994-95 to 2016-17) for analysis and have concluded that incidence of NTMs on Indian exports to EU is positively co-related to the per capita GDP of India.
\end{abstract}

Keywords: EU, incidence, India, NTMs (Non-tariff measures), trade

\section{Introduction}

Indian economy has become the frontrunner over last decade and a half - achieving and sustaining a growth rate of over $6 \%$ in its national income. In line with global trade trends, Indian export sector has been growing and contributing significantly to the economy. Given its exports structure, the economy is well positioned to benefit from the structural changes in technology and emerging forces of globalization.

Since the introduction of economic reforms in 1990-91, India's performance has improved substantially. Its share in the global GDP (Gross Domestic Product) has been steadily increasing since then. From $1.0 \%$ in 1990, Indian economy's share in the global GDP climbed to 2.98\% in 2015 (Felbermayr, Mitra, Aichele, \& Gröschl, 2017). According to a recent report - "Europe and India: Relaunching a Troubled Trade Relationship, 2017", the share of Indian exports and imports in total world trade has been steadily increasing over time. The shares of Indian exports and imports in the world trade have increased from $0.60 \%$ and $0.39 \%$ in 1994 to $1.79 \%$ and $1.13 \%$ respectively. As per the estimates of the "World Economic Outlook (WEO)", this share is going to further increase in the years until 2020.

The European Union (EU) is a very important partner of Indian economy in international trade. According to EU-India Relations Factsheet (Note 1), "the EU is India's largest trading partner, accounting for $13.2 \%$ of India's overall trade, ahead of China (11.6\%) and the United States $(9.6 \%)$. India is the EU's $9^{\text {th }}$ largest trading partner, with the value of EU exports of goods to India amounting to $€ 41.7$ billion in 2017 . The total value of EU-India trade in goods stood at $€ 85.8$ billion in 2017. Major EU exports to India include engineering goods (37\%), gems 
and jewelry (16.8\%) and chemical and allied products (10.4\%). The primary EU imports include textiles and clothing (17.8\%), chemical and allied products (14.1\%) and engineering goods (15.2\%)."

Due to various multilateral and regional agreements, tariffs in international trade are constantly being cut and the policy makers around the world are focusing on using Non-Tariff Measures (NTMs) in trade. Indeed, NTMs are now a very important aspect in terms of controlling the worldwide trade in commodities.

Different studies show that the EU has been quite prolific in using non-tariff measures vis-à-vis its trading partners. But in case of India, EU seems to be on an overdrive. The study by Rajesh Mehta (2005) on non- tariff barriers shows that nearly 25 percent of India's exports to European Union face the so-called non-tariff barriers, while this share is only 12 percent for the whole world.

The term "non-tariff measure" is used to define any official policy measure that implicitly or explicitly distorts international trade, other than the use of traditional tariffs. "United Nations Conference on Trade and Development (UNCTAD)", which has dedicated significant resources to defining, classifying and collecting data on NTMs, had established the "MAST (Multi-Agency Support Team)". A common definition for NTMs, first established by MAST, probably provides the most succinct definition available, which is as follows:

"NTMs are policy measures, other than ordinary customs tariffs, that can potentially have an economic effect on international trade in goods, changing quantities traded, or prices, or both.” MAST, 2009 (Note 2).

\section{Literature Review}

Baldwin (1970) defined NTM as, "any measure (public or private) that causes internationally traded goods and services or resources developed to the production of these goods and services, to be allocated in such a way as to reduce potential real-world income".

Mahe (1997) defined NTMs broadly to include Technical Barrier to Trade, Sanitary and Phytosanitary Measures, Transport and infrastructure costs, Telecommunications (comprising of internet connections, telephone and fax), Private product standards and Technical handling and red- tape.

NTMs have also been defined by Beghin et al. (2012) as regulated actions indirectly affecting the quantity and prices or both, of goods traded by changing the attributes and perception of customers.

"OECD (The Organisation for Economic Co-operation and Development)" defines non-tariff measures as "all measures other than the normal tariffs that have the effect of trade restriction among nations. All types of non-price restrictions and non-quantity restrictions on trade in goods, services and investment, both at federal and state level may be termed as non-tariff barriers according to EU. This comprises of both, border measures (customs procedures, etc.) and behind-the-border measures that may flow from domestic laws, practices and regulations."

Alan Deandoff (2012) has given the following classification of NTMs on the basis of intent and purpose of the policy:

Table 1. Classification of NTMs

\begin{tabular}{|c|c|c|c|}
\hline Policy & Purpose & Examples & Potential Consequences \\
\hline $\begin{array}{l}\text { Protectionist } \\
\text { policies }\end{array}$ & $\begin{array}{l}\text { To help domestic firms and } \\
\text { enterprises at the expense } \\
\text { of other countries. }\end{array}$ & $\begin{array}{l}\text { Import quotas; local content requirements; } \\
\text { public procurement practices }\end{array}$ & $\begin{array}{l}\text { Challenges levied at WTO and } \\
\text { other trade forums }\end{array}$ \\
\hline $\begin{array}{l}\text { Assistance } \\
\text { policies }\end{array}$ & $\begin{array}{l}\text { To help domestic firms and } \\
\text { enterprises, but not at the } \\
\text { expense of other countries. }\end{array}$ & $\begin{array}{l}\text { Domestic subsidies; anti-dumping laws; } \\
\text { industry bailouts. }\end{array}$ & $\begin{array}{l}\text { Adversely affected countries may } \\
\text { respond to protect themselves } \\
\text { (i.e., imposing countervailing } \\
\text { duties and subsidies). }\end{array}$ \\
\hline $\begin{array}{l}\text { Nonprotectionist } \\
\text { policies }\end{array}$ & $\begin{array}{l}\text { To protect the health and } \\
\text { safety of people, animals, } \\
\text { and plants; to protect or } \\
\text { improve the environment. }\end{array}$ & $\begin{array}{l}\text { Licensing, packaging, and labeling } \\
\text { requirements; sanitary and phytosanitary (SPS) } \\
\text { rules; food, plant and animal inspections; } \\
\text { import bans based on objectionable fishing or } \\
\text { harvesting methods. }\end{array}$ & $\begin{array}{l}\text { Limited formal consequences } \\
\text { lead to efforts to establish } \\
\text { common standards or mutual } \\
\text { recognition of different standards. }\end{array}$ \\
\hline
\end{tabular}

Source: https://www.usaid.gov/sites/default/files/documents/1861/Nontariff_barriers.pdf.

The existing literature do provide information on various methods used in measuring non-tariff measures. Deb (2006) in his study on "Rules of Origin and Non-Tariff Barriers in Agricultural Trade" had tabulated these 
methods and with the passing time more studies measuring NTMs have been added to the table. These measures are inclusive of both econometric as well as non-econometric approaches. The frequency or coverage approach, survey- based approach and price wedge approaches are included in non-econometric approaches. The econometric approach comprises of gravity models, augmented gravity models and CGE (Computable Generalised Equilibrium) analysis.

Each method has its own strengths and liabilities. Which method to use will depend upon the purpose of the study, for example surveys can help in determining which specific measure is important to exporters, but the cost incurred in the survey method is very high. Also, as noted by Carrere and de Melo (2011), surveys when conducted on various products and various countries are not necessarily suitable to be compared with one another since there will be difference in the standard level used for comparison in different countries.

One of the popular methods to quantify non-tariff measures is the inventory method (Beghin \& Bureau, 2001). The common use of this method may be seen in regulations or standards, various detentions and industry complaints. This method is based on count variable, i.e., various rules and actions which are imposed in these areas are subject to counting, which in effect creates the NTM variables to be used for analysis. Limitations of inventory approach is that it does not show differences in the impact of NTMs and types of various standards.

While examining the impact of NTMs on trade, the gravity model often uses the count variable (Beghin \& Bureau, 2001). The count of standards and other non-tariff measures have been used in different studies and one such study was done by Swann at el. (1996).

When it comes to reflecting the incidence of the NTMs, frequency ratio is the best method. This ratio does not show the impact of various standards on prices, trade and welfare. However, it provides the occurrence of the NTMs, which is very valuable information. The biggest advantage of using the frequency index is that this index does not suffer from the endogeneity of weights in the import value.

In order to study the incidence of non-tariff measures on trade, one of the methods might be to compare the actual imports into the importing country which is imposing NTMs with the imports that would have been in a free trade situation. This would give a clear picture of the incidence of NTMs on the export of a country. But this kind of comparison is not possible with any methods available, therefore a common practice to access the incidence of NTMs on imports is by using the Trade Coverage Ratios. Trade coverage ratios measure the total imports (by value) subject to a given NTM. These ratios are able to indicate the extent of non-tariff measures rather than specifying the effects of these measures on prices, production, consumption and import volumes. Trade coverage ratios do indicate the share of trade which is affected by a given non-tariff measure, not the degree of restrictiveness of a given measure (Clark et al., 1994).

NTBs influence the volume and pattern of trade through quantitative limitations or through their effect on relative costs and prices. They can distort trade and can have the negative influence on national welfare. NTBs artificially raise the price of the restricted good, increase its domestic production and in turn, attract resources in the protected industry (Sanchez, 1987).

As per WTO (2012), studies conducted in the field of quantifying the effect of non- tariff measures found that NTM's impact on trade is actually almost twice as much as that of tariff. There are studies conducted to show the impact of reduction in NTMs on the improvement in trade. One such study by Hoekman and Nicita (2011), shows that a reduction in NTMs by 5 percent will improve have an impact of improving trade by 2-3 percent.

Dhar and Kallummal (2007), have identified three effects that may arise from the impact of NTMs. These effects may be categorized as a) regulatory protection effect (in terms of rent to domestic sector); b) supply shift effect (in terms of compliance cost impact because of increase in domestic supply); and c) demand shift effect (in terms of new information effect, which leads to demand increase). Welfare oriented approach is the basis of discussion of regulatory protection, supply shift and demand shift effects. The effects have to be viewed in the context of mercantilist approach, and they are in the form of compliance costs and decisions regarding market entry (Melitz, 2003).

Impact of NTMs on trade may have both the directions- positive as well as negative. Positive impact may be in the form of enhancing trade, while the negative impact may be in the form of impeding trade resulting in losses (financial as well as non-financial). Increase in the cost of compliance is a form of financial loss. Non-financial losses may be in the form of firms becoming less competitive in the domestic market of importing country. The reasons for this may include slower time to market, local firms getting subsidies as well as other preferential treatment by the government of the importing country to protect the local firms.

Indian economy faces lots of challenges while complying to the strict SPS measures introduced by the developed 
nations, as noted by Mehta and George (2003). Because of developed nations' stringent measures, many times Indian exporters have no option but to exit the market or find other alternative markets.

Mehta (2009) in "Non-Tariff Barriers affecting India's Exports, Final Technical paper on NTB" identified the types of non-tariff barriers face by Indian exporters when they trade with developed nations. His observation from the study showed that nearly one fourth of imports from India to EU face the so-called NTBs, while for the world as a whole this share is only 12 percent.

According to Global Monitoring Report 2005, there is negative correlation between trade restrictiveness index and income per capita of a country. It can be inferred that the higher is a country's GDP per capita, the lower is its trade restrictiveness. Similarly, the higher is a country's GDP per capita, the lower are the trade barriers imposed by the rest of the world on its exports. So, it can be stated that negative association is found between GDP per capita and the restrictiveness of trade imposed by the importing countries on their imports and that imposed by the rest of the world on their exports.

Clark and Bruce (2006) also noted that non-tariff barriers' trade coverage falls gradually in the first third of the per capita income distribution, it falls less gradually for middle of the distribution and it then falls very rapidly with respect to the countries having highest per capita income.

Conforti et al. (2006) had done a study to analyse the extent of protection faced by the exporters in few countries. Results indicated that despite the expression on trade preferences, the exporters from developing economies seems to be largely constrained while engaging in trade with developed country markets, for example, EU, Japan and US.

Dean et al. (2009) noted a high correlation in few sectors between the restrictiveness of non-tariff measures and income of the country. While it is a general notion that affluent economies do have more open markets in comparison to the poor economies, evidence from the study shows that the restrictiveness of non-tariff measures might rise or fall as the country's income rises.

Carrère and Melo (2011) in their paper on "Notes on Detecting the Effects of Non-Tariff Measures" conclude that when compared to tariff measures, non-tariff measures are more restrictive. It was also noted in the study that low-income economies do face more restricted market entry conditions than the high-income economies.

Bratt (2014) in his working paper on "Estimating the bilateral impact of non-tariff measures (NTMs)" shared that estimated ad-valorem equivalents (AVEs) in the study imply that the exporters from low-income economies are more positively affected by the non-tariff measures forced by the high-income economies.

The findings of Ronen (2017)'s study on "Tariffs and Non-Tariff Measures: Substitutes or Complements. A Cross Country Analysis", are consistent with the study by Michalopoulos (1999), who noted that the frequency ratios of price and quantity control measures are likely to be higher in the economies having lower levels of GDP per capita and lesser degrees of openness for trade.

\section{Research Objectives and Rationale of the Study}

EU being the biggest and strategic trading partner of India, it becomes very important to study India-EU trade partnership in detail. Primary sector in the EU enjoys more protection than the secondary sector. Though, the overall rate of protection in the EU has seen a decline during the last decades, it does not guarantee that free trade policies would be followed in the country. EU is one of the most active initiators of non-tariff barriers in international trade. It certainly ranks high vis-à-vis India, when it comes to use of NTMs.

As discussed in the literature review, many studies have been conducted in the past on incidence of NTMs on exporting country's trade. The studies have also explored the interplay of incidence of NTMs and per capita GDPs of the exporting country. No comprehensive study on impact of NTM and GDP between India and EU has been reported in the literature. Present study does the analysis of the relationship between incidence of NTMs and per capita income of India as exporting country. The study was based on hypothesis that incidence of NTM is negatively co-related to the per capita GDP of the exporting country. Thus, the study intended to achieve the following objectives:

- To look into India-EU trade partnership, the various types of NTM from EU on Indian exports and assess the incidence of these NTMS at different points of time

- To measure the change in incidence of NTMs, for trade between EU and India, as the per capita GDP increases over a period of time (EU being the importer and GDP referred being that of India) 


\section{Data and Research Methodology}

The study relied extensively on the secondary data of tariffs and non-tariff measures being compiled by UNCTAD (TRAINS database). TRAINS is a comprehensive database at the most disaggregated level of Harmonized System (HS), covering tariff and non-tariff measures as well as import flows by origin for more than 150 countries.

Non-tariff measures included in the database were the measures such as sanitary and phytosanitary measures, technical barriers to trade, price control measures, quantity control measures, para- tariff measures, finance measures, trade-related investment measures and all other measures included in the TRAINS database.

The relationship between the incidence of non-tariff measures and the per capita GDP was tested in the Indian context (Net National Income has grown at an average pace of 5.5\% during 2000-01 and 2009-10). Data was analyzed through Correlation. Principal variables under analysis were the incidence of NTMs - measured through coverage ratio and per capita GDP.

\subsection{India-EU Relations}

India has been one of the few initial countries since the time European countries decided to organize them under the umbrella of "European Economic Community (EEC)". India established diplomatic relations with the group in 1962, while the group itself came into existence in 1958. It must be noted that India already had diplomatic and economic relations with the constituent countries prior to 1958. This was followed by a commercial co-operation agreement in 1973 and an Economic co-operation agreement in 1981. The relationship was elevated from trade to wider economic co-operation through a partnership development signed in 1994. This partnership was expanded into a strategic partnership in 2004 - India-EU summit held at the "The Hague". A "Joint Action Plan (JAP)" was adopted in 2005 which was further reviewed in 2008. The objective of the JAP was to strengthen the dialogue consultation mechanism covering the economic and political domains, enhance the trade investment and encourage people to people contact to help bring people and cultures together.

Table 2. Chronology of EU-India partnership

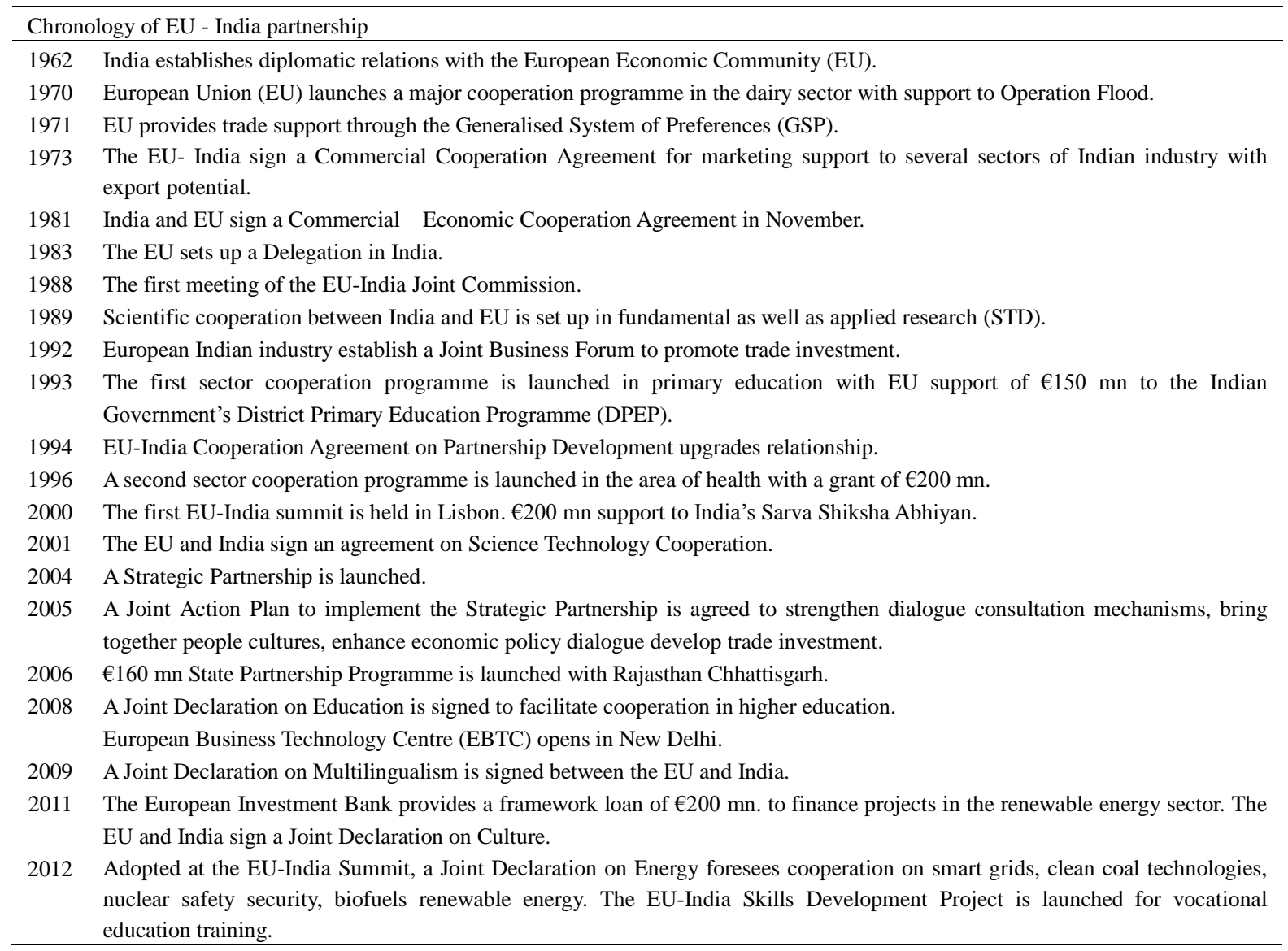

Source: http://eeas.europa.eu/archives/delegations/india/documents/publications/the_eu_and_india_fifty_years_of_partnership.pdf. 


\subsection{Economic and Commercial Relations}

Bilateral trade between India and the EU (as shown in table 3) was valued at $€ 77021$ million during 2016 as compared to $€ 77589$ million in 2015, indicating a fall of $0.73 \%$. Indian exports in 2016 decreased to $€ 37745$ million from $€ 38125$ million in 2015, indicating a fall of $0.99 \%$. Similar pattern was observed in India's imports from the European Union which was valued at $€ 39276$ million in 2016 and $€ 39464$ million in 2015, showing a fall of $0.48 \%$.

Trade improved in 2017 and was valued at $€ 85911$ million (11.40\% increase from 2016). Exports from Indian economy to the European Union valued at $€ 41723$ million during 2017 and $€ 37780$ million in 2016, indicating an increase of $10.44 \%$. Similarly imports of India from the EU valued at $€ 44184$ million in 2017 and $€ 39339$ million in 2016, indicating an increase of $12.32 \%$.

Table 3. EU - trade with India

\begin{tabular}{cccc}
\hline EU - Trade with India ( $\boldsymbol{\ell}$ million) & & \\
\hline Year & Imports & Exports & Total Trade \\
\hline 2007 & 26,666 & 29,181 & 55,847 \\
2008 & 29,632 & 31,356 & 60,988 \\
2009 & 25,503 & 27,499 & 53,003 \\
2010 & 33,464 & 34,985 & 68,488 \\
2011 & 39,927 & 40,648 & 80,575 \\
2012 & 37,528 & 38,595 & 76,123 \\
2013 & 36,842 & 35,959 & 72,801 \\
2014 & 37,170 & 35,655 & 72,825 \\
2015 & 39492 & 38,125 & 77,617 \\
2016 & 39,339 & 37,780 & 77,119 \\
2017 & 44,184 & 41,723 & 85,911 \\
\hline
\end{tabular}

Source: http://trade.ec.europa.eu/doclib/docs/2006/september/tradoc_113390.pdf.

To put this in perspective, Indian trade basket stood at $€ 646,251$ million during 2017 as compared to $€ 558,978$ million in 2016, as shown in table no. 4. This means trade with EU amounted to $13.3 \%$ of India's trade basket in 2017. Within this, exports to EU formed $16.0 \%$ of India's total exports, while imports to EU formed $11.5 \%$ of India's imports basket in 2017.

Table 4. India- trade with the World

\begin{tabular}{|c|c|c|c|c|c|c|}
\hline \multicolumn{7}{|c|}{ India - Trade with World ( $€$ million) } \\
\hline Year & Imports & $\%$ growth & Exports & $\%$ growth & Total Trade & $\%$ growth \\
\hline 2007 & 171,207 & & 111,893 & & 283,100 & \\
\hline 2008 & 218,520 & 27.6 & 132,618 & 18.5 & 351,138 & 24.0 \\
\hline 2009 & 184,721 & -15.5 & 118,432 & -10.7 & 303,153 & -13.7 \\
\hline 2010 & 264,600 & 43.2 & 168,143 & 42.0 & 432,743 & 42.8 \\
\hline 2011 & 334,104 & 26.3 & 220,578 & 31.2 & 554,682 & 28.2 \\
\hline 2012 & 381,698 & 14.3 & 231,318 & 4.9 & 613,016 & 10.5 \\
\hline 2013 & 352,337 & -7.7 & 237,249 & 2.6 & 589,586 & -3.8 \\
\hline 2014 & 346,633 & -1.6 & 239,156 & 0.8 & 585,789 & -0.6 \\
\hline 2015 & 353,526 & 2 & 239,901 & 0.3 & 593,427 & 1.3 \\
\hline 2016 & 322,405 & -8.8 & 236,573 & -1.4 & 558,978 & -5.8 \\
\hline 2017 & 384,908 & 19.6 & 261,343 & 10.5 & 646,251 & 15.7 \\
\hline
\end{tabular}

Source: http://trade.ec.europa.eu/doclib/docs/2006/september/tradoc_113390.pdf.

India exported $€ 11849$ million of services to EU in 2014 as compared to $€ 11506$ million in the previous year - a growth of $2.98 \%$. Imports of services by India from the Union on the other hand were $€ 11138$ million during 2014 , over $€ 12208$ million during 2013 - a negative growth of $8.76 \%$. The group of $28 \mathrm{EU}$ countries is India's leading partner in trade. It is India's number one partner in exports market, while for imports, EU is at second position. 
Let us look at this from EU's perspective. EU's trade basket stood at $€ 3,737,688$ million during 2017 as compared to $€ 3,453,564$ million in 2016, showing a growth rate of $8.1 \%$. Though it had shown a decline in 2016, compared to 2015

Table 5. EU - trade with World

\begin{tabular}{ccccccc}
\hline \multicolumn{2}{c}{ EU - Trade with World $(€$ million $)$} & \multicolumn{7}{c}{} \\
\hline Year & Imports & \% growth & Exports & \% growth & Total Trade & \% growth \\
\hline 2007 & $1,450,340$ & & $1,234,482$ & & $2,684,822$ & \\
2008 & $1,585,231$ & 9.3 & $1,309,147$ & 6.1 & $2,894,378$ & 7.8 \\
2009 & $1,235,636$ & -22.1 & $1,093,961$ & -16.4 & $2,329,598$ & -19.5 \\
2010 & $1,531,518$ & 24 & $1,354,055$ & 23.8 & $2,885,573$ & 23.9 \\
2011 & $1,729,980$ & 13 & $1,554,511$ & 14.8 & $3,284,491$ & 13.8 \\
2012 & $1,798,757$ & 4 & $1,684,928$ & 8.4 & $3,483,686$ & 6.1 \\
2013 & $1,687,701$ & -6.2 & $1,736,501$ & 3.1 & $3,424,202$ & -1.7 \\
2014 & $1,692,791$ & 0.3 & $1,703,850$ & -1.9 & $3,396,640$ & -0.8 \\
2015 & $1,729,207$ & 2 & $1,789,154$ & 5.1 & $3,518,361$ & 3.6 \\
2016 & $1,708,318$ & -1 & $1,745,247$ & -2.5 & $3,453,564$ & -1.8 \\
\hline
\end{tabular}

Source: European Commission, Directorate- General for Trade.

EU's trade with India amounted to $2.23 \%$ of its trade basket. Within this, exports to India formed $2.16 \%$ of EU's total exports, while imports to India formed $2.3 \%$ of India's imports basket. While EU is the biggest trading partner for India, from EU perspective, India ranks $9^{\text {th }}$ in terms of trade partnerships.

European Union is considered to be big source of "Foreign Direct Investment" for Indian economy.

FDI from EU to India saw a continuous increase. It was $€ 3.5$ billion in 2009 and increased to $€ 7.5$ billion in 2010 and further to $€ 14.19$ billion in 2011. On the other hand, India's FDI to the European Union saw a fall. It fell to $€ 0.48$ billion in 2010 from $€ 0.945$ billion in 2009. But things improved and FDI from India to EU rose to around $€ 2$ billion in 2011. Netherlands, Germany, the United Kingdom, Cyprus and France are among the prominent investors in India. Between April 2000 and March 2017, these countries contributed 21\% of the FDI flowing into India.

\subsection{Controlling the Flow of Trade between the EU and India}

When it comes to controlling the flow of trade, EU presents a contrasting picture between the use of "tariff and non- tariff measures". While the tariff rates are one of the lowest in the world, the EU is known as one of the most active initiator of NTMs in international trade. Numbers presented below confirm the above premise, especially with reference to trade between India and the EU. Please note that average tariff rate is much higher in India when comparing with EU for almost all the goods. Summary of the tariff rates in India in 2015 is shown in table 6 and the summary of the tariff rates in the EU in 2015 is shown in table 7. By comparing both the tables we can see that, for agricultural products, tariff rates are $113.5 \%$ in India as compared to $10.9 \%$ in EU, whereas for non-agricultural products the comparative numbers in India and the EU are $34.5 \%$ and $3.9 \%$ respectively. The average rate of tariff for all the products in India is $48.5 \%$, vis-à-vis $4.8 \%$ in the EU.

Table 6. Summary of tariff rate in India, 2015

\begin{tabular}{lccc}
\hline Summary & Total & Agri. Products & Non-Agri. Products \\
\hline Simple average final bound & 48.5 & 113.5 & 34.5 \\
Simple average MFN applied & 13.4 & 32.7 & 10.1 \\
Trade weight average & 7.0 & 47.2 & 4.9 \\
\hline
\end{tabular}

Source: https://www.wto.org/english/res_e/booksp_e/tariff_profiles16_e.pdf.

Table 7. Summary of tariff rate in EU, 2015

\begin{tabular}{lccc}
\hline Summary & Total & Agri. Products & Non-Agri. Products \\
\hline Simple average final bound & 4.8 & 10.9 & 3.9 \\
Simple average MFN applied & 5.1 & 10.7 & 4.2 \\
Trade weight average & 2.7 & 8.5 & 2.3 \\
\hline
\end{tabular}

Source: https://www.wto.org/english/res_e/booksp_e/tariff_profiles16_e.pdf. 
Following table (Table 8) shows duties faced by Indian exports in major trading partners. While tariff rates in India are higher vis-à-vis the EU, it must be noted that Indian exports face higher rates in the EU as compared to some of its other export markets. For example, in EU market, tariff face by Indian exports for agricultural products (at HS2 level) was 25\%. Similarly exports from India faced tariff of 109\% for HS-6-digit agricultural products, as against China $(10 \%, 13 \%)$, USA $(21 \%, 70 \%)$, Saudi Arabia $(19 \%, 58 \%)$, UAE (23\%, 96\%). By looking at the export of non-agricultural goods from India, it may be noted that these goods faced a tariff rate of $67 \%$ in the EU market. This rate is highest when we compare it to other key partners of EU such as USA (59\%), China (46\%), Hong-Kong-China (7\%) and UAE (54\%).

Table 8. Duties faced by Indian exports in Major Trading Partners (2014)

\begin{tabular}{lcc}
\hline Major Markets & \multicolumn{2}{c}{ 95\% Trade in no. of } \\
\cline { 2 - 3 } & HS 2-digit & HS 6-digit \\
\hline Agricultural products & 25 & 109 \\
European Union & 21 & 70 \\
United States of America & 19 & 58 \\
Kingdom of Saudi Arabia & 10 & 13 \\
China & 23 & 96 \\
United Arab Emirates & & 1205 \\
Non-Agricultural Products & 67 & 717 \\
European Union & 59 & 561 \\
United States of America & 54 & 18 \\
United Arab Emirates & 7 & 355 \\
Hong Kong, China & 46 & \\
China & & \\
\hline
\end{tabular}

Source: https://www.wto.org/english/res_e/booksp_e/tariff_profiles16_e.pdf.

In the EU, primary sector is more protected when compared to manufacturing sector. This is evident from the average final bound tariff rate applicable to agricultural products which is almost 2.8 times than that faced by non-agricultural products.

"The protection of EU's common market has reduced during the last decades due to international trade agreement's high costs for EU to maintain the policies. This has led to freer trade where countries can trade with each other easily and resources can be more effectively allocated. But even if the tariff has been lower, is there still protection when trading with agricultural commodities? This protection may be caused by things other than tariffs, such as non-tariff barriers, high transactions costs caused by bad institutions currency barrier." (Trade barriers on EU's agricultural market - Gustaf Svenungsson) (Note 3).

"The reduction in tariffs does not ensure operation of free trade; neither does it reduce protectionism; rather the protectionist tendency has penetrated into other areas as well in the form of several complicated non-tariff barriers," (Deardorff \& Stern, 1985).

As mentioned above, European Union is one of the most active initiators of NTMs in international trade. It certainly ranks high vis-à-vis India, when it comes to use of NTMs in controlling flow of trade protecting interests of domestic interest groups.

Table no. 9 also highlights the fact that most of the NTM measures, irrespective of the initiating country, have been initiated post the year 2000. It also points to growing protectionist tendencies governing the global trade flows.

Table 9. NTMs by select countries against RoW

\begin{tabular}{lcccc}
\hline Initiating country & \multicolumn{2}{c}{ Measures } & \multicolumn{2}{c}{ Specific Trade Concerns } \\
\cline { 2 - 4 } & $\mathbf{1 9 9 1 - 2 0 1 6}$ & $\mathbf{2 0 0 0 - 2 0 1 6}$ & $\mathbf{1 9 9 1 - 2 0 1 6}$ & $\mathbf{2 0 0 0 - 2 0 1 6}$ \\
\hline EU & 2332 & 1964 & 190 & 166 \\
United States of America & 5528 & 5012 & 93 & 39 \\
India & 1130 & 1059 & 86 & 88 \\
China & 2832 & 2677 & 41 & 38 \\
Japan & 1452 & 1199 & 36 \\
\hline
\end{tabular}

Source: https://i-tip.wto.org/goods/Default.aspx. 
Following table (table 10) shows a comparison between non-tariff measures used by EU against Indian exports and non-tariff measures used by India against exports from European union.

The data shows that the exporters from Indian economy do face many challenges in accessing EU markets because of non-tariff barriers imposed by EU. Sanitary and phytosanitary (712 measures impacting Indian exports and 190 measures impacting EU exports) and technical barriers to trade (1196 measures impacting Indian exports and 102 measures impacting EU exports) are the most frequent used measures by the EU.

Table 10. NTMs impacting EU and India (1991-2016)

\begin{tabular}{lclc}
\hline NTMs by EU Impacting India & & NTMs by India impacting EU & \\
\hline Type of NTMs & No. of Measures & Type of NTMs & No. of Measures \\
\hline Anti- dumping & 77 & Anti- dumping & 94 \\
Countervailing & 52 & NA & \\
Export Subsidies & 40 & NA & 118 \\
Quantitative Restrictions & 15 & Quantitative Restrictions & 190 \\
Sanitary and Phytosanitary & 712 & Sanitary and Phytosanitary & 100 \\
Special Safeguards & 54 & Safeguards & 18 \\
State Trading Enterprises & 2 & State Trading Enterprises & 6 \\
Tariff-rate quotas & 174 & Tariff-rate quotas & 102 \\
Technical Barriers to Trade & 1196 & Technical Barriers to Trade & 28 \\
Specific Trade Concerns & 22 & Specific Trade Concerns & \\
\hline
\end{tabular}

Source: https://i-tip.wto.org/goods/Default.aspx.

An OECD survey in 2011 established that NTM related trade costs on average add more to trade restrictiveness than tariffs itself. As we may note from the table below (Table 11) that the Non-Tariff measures related trade costs for EU are much higher than the MFN tariffs in both processed foods as well as motor vehicles.

Table 11. NTM costs tariffs (percent of import value)

\begin{tabular}{lcc}
\hline Processed foods & NTM related trade costs & Tariffs (MFN) \\
\hline Brazil & 39.5 & 14.1 \\
Canada & 23.3 & 18.5 \\
China & 44.8 & 13.7 \\
European Union & 30.1 & 21.3 \\
India & 36.5 & 48.1 \\
Korea & 37.9 & 33.5 \\
Russia & 69.1 & 15.7 \\
United States of America & 49.5 & 6.4 \\
Motor Vehicles & & \\
Brazil & 27.2 & 15.5 \\
Canada & 2.6 & 30.8 \\
China & 33.9 & 20.4 \\
European Union & 17.1 & 8.1 \\
India & 27 & 17.2 \\
Korea & 20.5 & 8.1 \\
Russia & 34.3 & 15.3 \\
United States of America & 14.9 & 2.3 \\
\hline
\end{tabular}

Source: http://www.oecd.org/officialdocuments/publicdisplaydocumentpdf/?cote=TAD/TC/WP(2010)37/FINAL\&docLanguage=En.

There are various arguments on the impact of NTM's on trade. Some arguments talk about trade impeding, others talk about trade promoting impacts. NTMs may lead to enhancement of trade as well as decrease in trade resulting in incurring losses. These losses may be due to the costs involved in compliance procedure and also due to the costs involved in providing subsidies by the government to protect local firms.

Following section tested the hypothesis of the study pertaining to the relationship between incidence of NTM and per capita GDP. 


\section{Result of the Analysis}

The data has been tested using Spearman Correlation Coefficient associated test of significance for the Correlation Coefficient.

A sample of the data is provided below:

Table 12. Sample data (GDP per capita and coverage ratio)

\begin{tabular}{|c|c|c|}
\hline Year & GDP/ capita (INR Lakh) & Coverage Ratio [total imports (by value) subject to a given NTM] \\
\hline 1994-95 & 10499 & $0.00576300 \%$ \\
\hline 1994-95 & 10499 & $0.34270306 \%$ \\
\hline 1994-95 & 10499 & $0.00007590 \%$ \\
\hline 1994-95 & 10499 & $0.00116301 \%$ \\
\hline 1994-95 & 10499 & $0.00116301 \%$ \\
\hline 1994-95 & 10499 & $0.00109751 \%$ \\
\hline 1994-95 & 10499 & $0.05347748 \%$ \\
\hline 1994-95 & 10499 & $0.02658326 \%$ \\
\hline 1994-95 & 10499 & $0.08006074 \%$ \\
\hline 1994-95 & 10499 & $0.08006074 \%$ \\
\hline 1994-95 & 10499 & $0.00226235 \%$ \\
\hline 1995-96 & 12054 & $0.80662831 \%$ \\
\hline 1995-96 & 12054 & $1.16485761 \%$ \\
\hline $1995-96$ & 12054 & $1.16485761 \%$ \\
\hline $1995-96$ & 12054 & $0.00086864 \%$ \\
\hline $1995-96$ & 12054 & $0.01751688 \%$ \\
\hline $1995-96$ & 12054 & $0.00117636 \%$ \\
\hline 1995-96 & 12054 & $0.00313288 \%$ \\
\hline $1995-96$ & 12054 & $0.23597119 \%$ \\
\hline $1995-96$ & 12054 & $0.04259608 \%$ \\
\hline $1995-96$ & 12054 & $0.00074955 \%$ \\
\hline $1995-96$ & 12054 & $0.00313288 \%$ \\
\hline $1995-96$ & 12054 & $0.01751688 \%$ \\
\hline 1995-96 & 12054 & $0.01751688 \%$ \\
\hline $1995-96$ & 12054 & $0.01751688 \%$ \\
\hline $1995-96$ & 12054 & $3.51560155 \%$ \\
\hline $1995-96$ & 12054 & $3.51560155 \%$ \\
\hline $1995-96$ & 12054 & $0.00662357 \%$ \\
\hline $1995-96$ & 12054 & $0.01751688 \%$ \\
\hline 1995-96 & 12054 & $1.64643180 \%$ \\
\hline 1995-96 & 12054 & $1.64643180 \%$ \\
\hline 1996-97 & 13761 & $0.12995957 \%$ \\
\hline 1996-97 & 13761 & $0.19085966 \%$ \\
\hline 1996-97 & 13761 & $0.05885904 \%$ \\
\hline 1996-97 & 13761 & $0.19150898 \%$ \\
\hline 1996-97 & 13761 & $0.00515260 \%$ \\
\hline 1996-97 & 13761 & $0.02103982 \%$ \\
\hline 1996-97 & 13761 & $0.00515260 \%$ \\
\hline 1996-97 & 13761 & $0.02103982 \%$ \\
\hline 1996-97 & 13761 & $0.43886933 \%$ \\
\hline 1996-97 & 13761 & $0.02204584 \%$ \\
\hline 1996-97 & 13761 & $0.15941550 \%$ \\
\hline $1997-98$ & 15017 & $0.00827298 \%$ \\
\hline $1997-98$ & 15017 & $0.03911731 \%$ \\
\hline 1998-99 & 16976 & $0.07161351 \%$ \\
\hline 1998-99 & 16976 & $0.08839745 \%$ \\
\hline
\end{tabular}


Table 13. Aggregated (year wise) analysis

\begin{tabular}{ccc}
\hline Year & GDP/ capita (INR Lakh) - Avg & Coverage Ratio [total imports (by value) subject to a given NTM] - Avg \\
\hline $1994-95$ & 10499 & $0.05403728 \%$ \\
$1995-96$ & 12054 & $0.69211229 \%$ \\
$1996-97$ & 13761 & $0.11308207 \%$ \\
$1997-98$ & 15017 & $0.02369515 \%$ \\
$1998-99$ & 16976 & $0.08000548 \%$ \\
$1999-00$ & 18563 & $0.13979021 \%$ \\
$2000-01$ & 19634 & $0.34045306 \%$ \\
$2001-02$ & 20916 & $1.21162952 \%$ \\
$2002-03$ & 22196 & $0.59954962 \%$ \\
$2003-04$ & 24495 & $1.24415890 \%$ \\
$2004-05$ & 27286 & $0.92835038 \%$ \\
$2005-06$ & 30656 & $0.60563374 \%$ \\
$2006-07$ & 35234 & $0.87313785 \%$ \\
$2007-08$ & 40264 & $0.46142227 \%$ \\
$2008-09$ & 45958 & $1.10872584 \%$ \\
$2009-10$ & 52213 & $0.25621123 \%$ \\
$2010-11$ & 61120 & $0.15267229 \%$ \\
$2011-12$ & 66450 & $0.28837742 \%$ \\
$2012-13$ & 74516 & $0.26725137 \%$ \\
$2013-14$ & 82839 & $0.36255315 \%$ \\
$2014-15$ & 90622 & $0.41604070 \%$ \\
$2015-16$ & 97106 & $0.86977861 \%$ \\
$2016-17$ & 105234 & $0.65696225 \%$ \\
\hline
\end{tabular}

Analysis of these numbers provide following result:

\section{Spearman Correlation Coefficient $\mathbf{=} \mathbf{0 . 2 9 1 5 0 1 9 7}$}

\section{p-value at $95 \%$ level of significance (test of significance) $=\mathbf{0 . 1 7 7 1 5 7 0 8}$}

\section{Since p-value $>0.05$, the correlation is statistically not significant.}

Furthering the analysis, the authors did a disaggregated (year wise) analysis, which resulted in following numbers.

The authors have used different permutations of data from the main data set (1994-95 to 2016-17) for analysis and arrived at following results:

The above results have been summarized in the below table:

\begin{tabular}{|c|c|c|c|}
\hline Dataset for following years & $\begin{array}{ll}\text { Spearman's } & \text { Correlation } \\
\text { Coefficient }\left(R_{s}\right) & \\
\end{array}$ & p- value & Whether (r) is Significant \\
\hline \multicolumn{4}{|l|}{$1994-95$ to $2016-17$} \\
\hline With Outliers & $\begin{array}{l}0.07133333 \\
\text { (weak correlation) }\end{array}$ & 0.09680983 & Statistically not significant since p-value $>0.05$ \\
\hline After Removing Outliers & $\begin{array}{l}0.63107346 \\
\text { (moderately strong relationship) }\end{array}$ & 0.00000000 & $\begin{array}{l}\text { Statistically significant since p-value }<0.05 \\
\text { (there is almost negligible chance that the } \\
\text { correlation is a result of chance) }\end{array}$ \\
\hline \multicolumn{4}{|l|}{$2000-01$ to $2016-17$} \\
\hline With Outliers & $\begin{array}{l}0.00062439 \\
\text { (very weak relationship) }\end{array}$ & 0.98897790 & $\begin{array}{l}\text { Statistically not significant since p-value }>0.05 \\
\text { (there is over } 98 \% \text { probability that the correlation } \\
\text { is a result of chance) }\end{array}$ \\
\hline After Removing Outliers & $\begin{array}{l}0.67153635 \\
\text { (moderately strong relationship) }\end{array}$ & 0.00000000 & $\begin{array}{l}\text { Statistically significant since p-value }<0.05 \\
\text { (there is almost nil probability that the correlation } \\
\text { is a result of chance) }\end{array}$ \\
\hline
\end{tabular}

Scatter diagrams of all the four situations are given below: 


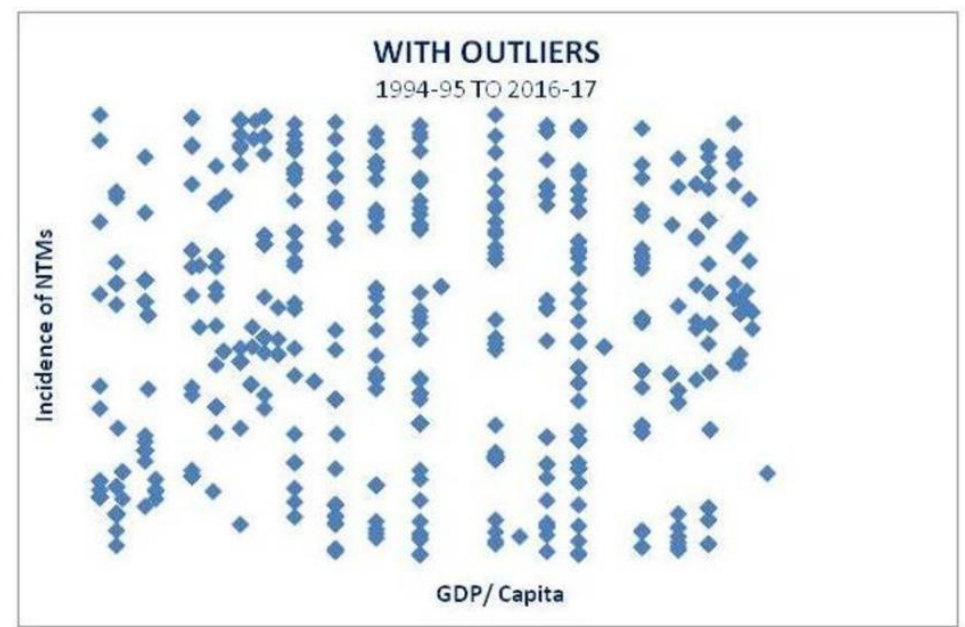

Figure 1. 1994-95 to 2016-17- With Outliers

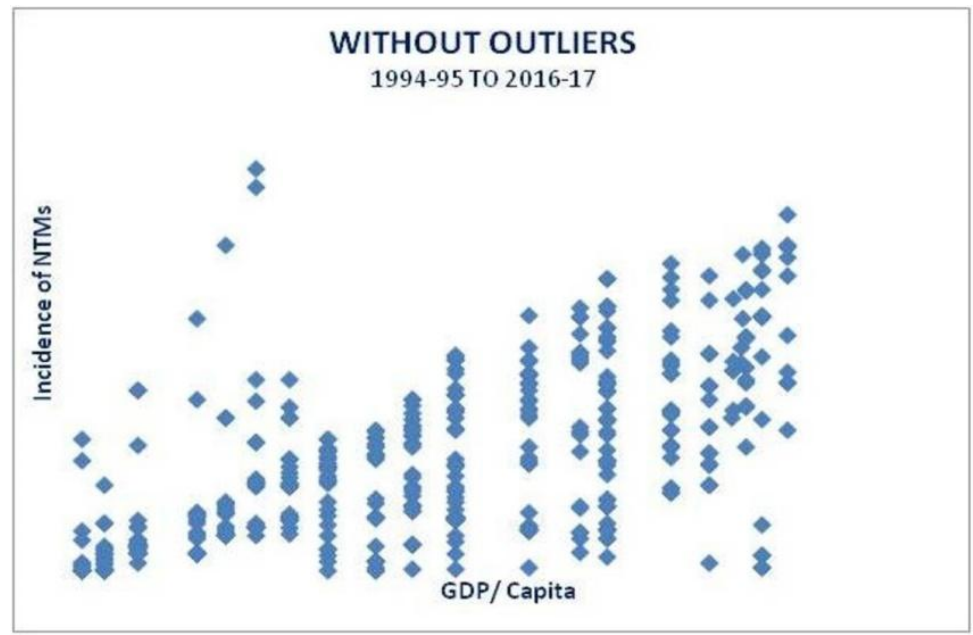

Figure 2. 1994-95 to 2016-17- Without Outliers

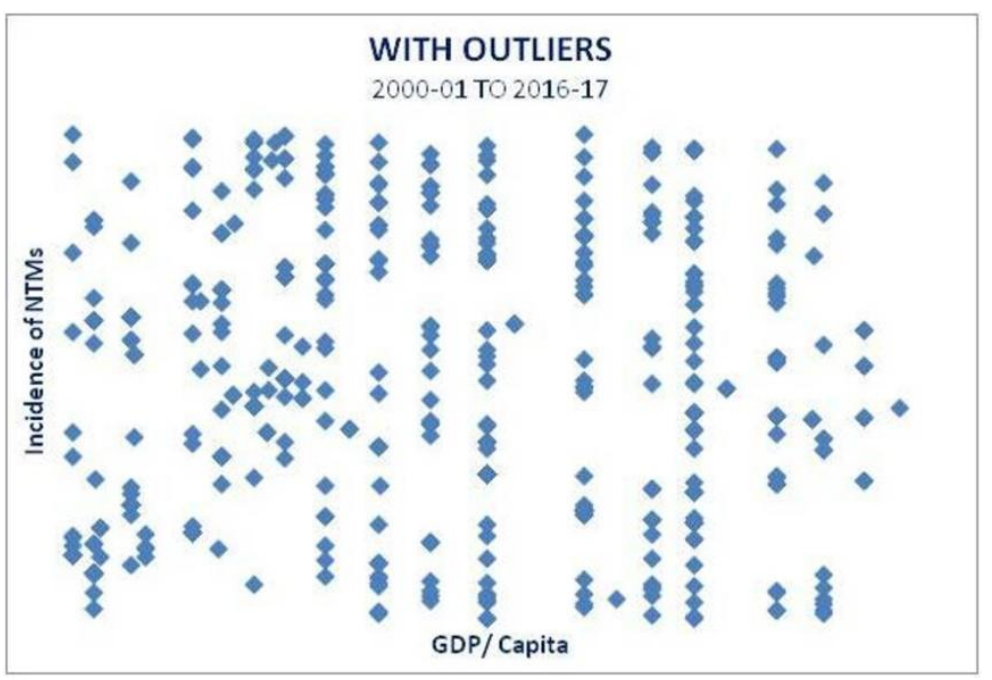

Figure 3. 2000-01 to 2016-17 - With Outliers 


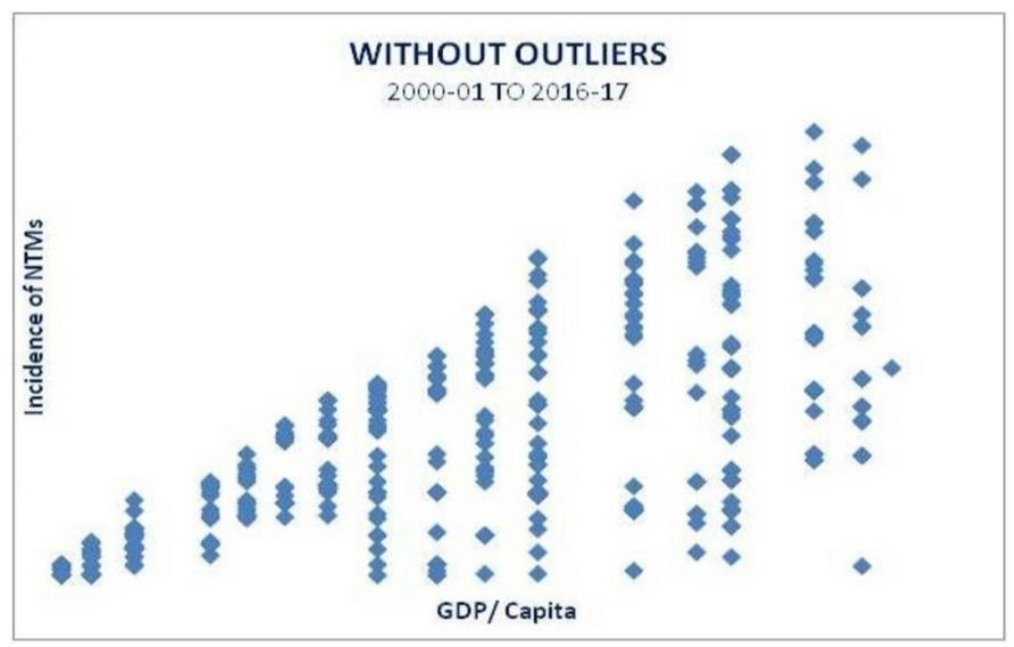

Figure 4. 2000-01 to 2016-17 - Without Outlier

\section{Inference Drawn from the Results}

Following inference can be drawn from the above table:

- As against our hypothesis, incidence of NTMs on Indian exports to EU is positively co-related to the GDP per capita of India, irrespective of the period of study - whether 1994-95 to 2016-17 or 2000-01 to 2016-17. In both the instances, correlation is statistically significant.

- 1994-95 to 2016-17 - Statistically significant since p-value $<0.05$ (there is almost nil probability that the correlation is a result of chance)

- 2000-01 to 2016-17 - Statistically significant since p-value $<0.05$ (there is almost nil probability that the correlation is a result of chance)

The statistical significance establishes that the relationship value can be relied upon for taking any significant policy decision.

\section{Study Limitations}

The study relies on the data provided by UNCTAD-TRAINS, WTO IDB and CTS databases, as well as UN COMTRADE on Non-Tariff Measures. This data in turn is supplied to UNCTAD, etc. by the imposing countries. By their very natures, NTMs are discriminatory and arbitrary in nature. The imposing countries thus have an incentive to under report the data. This implies that the data may not be exhaustive and may not cover all the NTMs being imposed.

The data collection methodology has undergone frequent changes in the past which means that every time any change is made to the data methodology, existing and fresh studies have to be adjusted and viewed from the perspective of new methodology, to keep them relevant and aligned to current data sets.

\section{Policy Implication and Future Scope}

The original hypothesis in the study was that incidence of NTM is negatively co-related to the per capita GDP of the exporting country. But the result of the study shows that the incidence of non-tariff measures on Indian exports to EU is positively co-related to the per capita GDP of India. Therefore, the study does not support the hypothesis.

The literature says that with an increase in per capita GDP, the incidence of NTMs should reduce on the exporting country, but this is not the case with Indian economy. The result of the study indicates that even after increase in the GDP and India moving from low income to middle income, the incidence of NTMs on Indian exports to EU is increasing. India will have to take proactive measures to guard itself against NTMs. This implies higher vigilance and activism on part of Indian authority to constantly push down the level of protection in terms of non-tariff measure and conclude the proposed FTA with EU at favourable terms as soon as possible.

\section{Acknowledgements}

The authors are grateful to anonymous referees of the journal for their extremely useful suggestions for improving the quality of the paper. Usual disclaimers apply. 


\section{References}

Baylis, K., Nogueira, L., \& Pace, K. (2010). Food Import Refusals: Evidence from the European Union. American Journal of Agricultural Economics, 93(2), 566-572. https://doi.org/10.1093/ajae/aaq149

Beghin, J. C., \& Bureau, J. C. (2001). Quantification of Sanitary, Phytosanitary and Technical Barriers to Trade for Trade Policy Analysis. Centre for Agricultural and Rural Development, Working Paper 01-WP 291, IOWA State University, 1-37. Retrieved from https://works.bepress.com/john-beghin/68/

Beghin, J. C., Disdier, A. C., Marette, S., \& Van, T. F. (2012). Welfare costs and the benefits of non-tariff measures in trade: a conceptual framework and application. World Trade Review, 11(33), 356-375. https://doi.org/10.1017/S1474745612000201

Carrere, C., \& Melo, J. D. (2011). Non-tariff measures: what do we know, what should be done? Journal of Economic Integration, 26(1), 169-196. https://doi.org/10.11130/jei.2011.26.1.169

Clark, D. P., \& Simonetta, Z. (1994). Non-Tariff Measures and United States' CBERA-Eligible Products. journal of Development Studies, 31(1).

Deardorff, A., \& Stern, R. (1985). The Structure of Tariff Protection: Effects of Foreign Tariffs Existing NTBs. The Review of Economics Statistics, 67(4), 539-48. https://doi.org/10.2307/1924797

Deb, U. K. (2006). Rules of Origin and Non-tariff Barriers in Agricultural Trade: Perspectives from Bangladesh and Cambodia. Asia Pacific Research and Training Network on Trade, ARTNeT Working paper Series, No. 12. Retrieved from http://www.unescap.org/sites/default/files/AWP\%20No.\%2012.pdf

Disdier, A. C., \& Marette, S. (2010). The combination of gravity and welfare approaches for evaluating non-tariff measures. American Journal of Agricultural Economics, 92(3), 713-726. https://doi.org/10.1093/ajae/aaq026

Felbermayr, G., Mitra, D., Aichele, R., \& Gröschl, J. (2017). Europe and India: Relaunching a Troubled Trade Relationship. IFO Center for International Economics, No. 80.

Gourdon, J., \& Nicita, A. (2012). NTMs: Interpreting the New Data. In O. Cadot, \& M. Malouche (Eds.), Non-tariff Measures: A Fresh Look at Trade Policy's New Frontier. Washington, D.C.: Centre for Economic Policy Research and World Bank.

Grant, J., \& Anders, S. (2010). Trade deflection arising from US import refusals and detentions in fishery and seafood trade. American Journal of Agricultural Economics, 93(2), 573-580.

Hoekman, B., \& Nicita, A. (2011). Trade Policy, Trade Costs, and Developing Country Trade. World Development, 39(12), 2069-79. https://doi.org/10.1016/j.worlddev.2011.05.013

Liu, L., \& Yue, C. (2009). Non-tariff Barriers Caused by SPS Measures and Customs Procedures with Product Quality Changes. Journal of Agricultural and Resources Economics, 34(1), 196-212.

Mahe, L. P. (1997). Environment and quality standards in the WTO: New protectionism in agricultural trade? A European perspective. European Review of Agricultural Economics, 24(3-4), 480-503. https://doi.org/10.1093/erae/24.3-4.480

MAST. (2008). Multi-Agency Support Team First Progress Report to the Group of Eminent Persons on Non-tariff Barriers. June report, Mimeo, Geneva, UNCTAD.

Mehta, R. (2005). Non-Tariff Barriers Affecting India's Exports. RIS Discussion Paper No. 97, RIS New Delhi.

Mehta, R., \& George, J. (2003). Processed food products exports from India: and exploration with SPS regime. Project Report, Australian National University of Melbourne, Research and Information.

Melitz, M. (2003). The impact of trade on intra-industry reallocations and aggregate industry productivity. Econometrica, 71(6), 1695-725. https://doi.org/10.1111/1468-0262.00467

Otsuki, T., Wilson, J. S., \& Sewadeh, M. (2001). Saving two in a billion: quantifying the trade effect of European food safety standards on African exports. Food Policy, 26(5), $495-514$. https://doi.org/10.1016/S0306-9192(01)00018-5

Sanchez, A. (1987). Non-Tariff Barriers in ASEAN-Japan and intra-ASEAN trade. ASEAN Economic Bulletin. https://doi.org/10.1355/AE4-1A

Swann, P., Temple, P., \& Shurmer, M. (1996). Standards and trade performance: the UK experience. Economic Journal, 106(438), 1297-313. https://doi.org/10.2307/2235522 
WTO. (2012). Trade and Public Policies: A Closer Look at Non-tariff Measures in the 21st Century. World Trade Report, Geneva: World Trade Organization.

\section{Notes}

Note 1. https://eeas.europa.eu/delegations/india/4010/node/4010_lo

Note 2.

http://siteresources.worldbank.org/INTRANETTRADE/Resources/Pubs/303936-1334932249017/SNM_Chapter 1.pdf

Note 3. https://stud.epsilon.slu.se/9416/1/svenungsson_g_160831.pdf

\section{Copyrights}

Copyright for this article is retained by the author(s), with first publication rights granted to the journal.

This is an open-access article distributed under the terms and conditions of the Creative Commons Attribution license (http://creativecommons.org/licenses/by/4.0/). 